\title{
ERÄITÄ KASVIPATOLOGISIA NÄKÖKOHTIA SYYSVILJOJEN JA NURMIHEINIEN TALVEHTIMISESTA.
}

Selostus esitelmästä, joka pidettiin koetoimintapäivillä Helsingissä 25. II. 1947.

\author{
H. EKSTRAND.
}

\section{Statens Växtskyddsanstalt, Tukholma, Ruotsi.}

Ennen kuin saadaan määritetyksi eräiden kasvien oraissa ilmenevien vahinkojen perussyyt, tarvitaan pitkäaikaisia tutkimuksia. Monesti voi tällöin eri aloja edustavien koetoimintamiesten yhteistyö johtaa nopeasti tuloksiin. Varsinkin jos kasvipatologisen tutkimustoiminnan ja muun kasvinviljelykoetoiminnan välistä yhteistyötä lisätään, voivat molempien puolien saavuttamat tulokset koitua verraten lyhyessä ajassa maatalouden ja kasvinviljelyn hyödyksi.

Kun esitetään yhteenvetoja satotuloksista, on tähän saakka tavallisesti kiinnitetty päähuomio satolukuihin, jotka eri vuosina suuresti vaihtelevat. Näiden vaihtelujen syitä ei kuitenkaan ole lähemmin selvitetty eikä niihin tavallisesti ole kokeita arvosteltaessa kiinnitetty mitään huomiota. Paikalliskokeiden tarkoituksena on selvittää, mikä kasvilajike tai kasvilajien yhdistelmä on sopivin paikkakunnalla viljeltäväksi, mikä on sopivin lannoitus, paras kylvöaika jne. Sen sijaan ovat puhtaasti kasvipatologiset kysymykset useinmmissa tapauksissa jääneet aivan liian vähäisen huomion kohteeksi. Monesti kasvitaudit kuitenkin aiheuttavat siksi suuria sadon vähennyksiä, että pelkät satoluvut saattavat antaa eräistä lajikkeista virheellisen kuvan. Seuraavassa esitän eräitä syysviljojen ja nurmikasvien talvehtimista koskevia tutkimustuloksiani, jotka osoittavat, että koetoiminnan on välttämättä oltava entistä kiinteämmässä yhteistyössä kasvipatologisen tutkimuksen kanssa ja että siten voidaan saavuttaa entistä nopeampia ja parempia tuloksia kasvinviljelykokeista.

Jo useita vuosia sitten tehdessäni keväällä havaintoja syysviljojen lajikekokeista minusta näytti siltä, että osa eri lajikkeiden oraissa esiintyvistä eroavuuksista saattaa johtua niiden erilaisesta kestävyydestä sienien aiheuttamia kasvitauteja, mm. lumihometta vastaan. Kysymyksen selvittämiseksi järjestettiin syysrukiilla lajikekokeita, joissa jokaisesta siemenerästä oli sekä peittaamaton että peitattu koejäsen. Osa lajikkeista käsitti useita näytteitä, jotta saataisiin samasta 
lajikkeesta eri tavalla saastunutta aineistoa. Kokeita on suoritettu usean vuoden aikana eri tahoilla Ruotsia Skånesta aina Norrbotteniin saakka. Näiden kokeiden tarkastusmatkoilla olen samalla tarkastanut muita syysvilja- ja nurmikasvikokeita, joita ovat järjestäneet talousseurat, valtion koeasemat ja Ruotsin kylvösiemenyhdistyksen haaraosastot. Keväällä 1946 Suomeen tekemälläni matkalla minulla oli tilaisuus käydä useilla Suomen koeasemilla, joista myös saatiin hyviä kasvien talvehtimista selvittäviä kokemuksia. Osa näistä havainnoista ja tutkimustuloksista on julkaistu Ruotsin valtion kasvinsuojelulaitoksen julkaisusarjoissa (EKSTRAND, 2-16).

\section{Fus arium-sienien merkitys.}

ÅKERMAN ja hänen työtoverinsa (1927 ja myöhemmin)) ovat osoittaneet, että syysvehnälajikkeiden kylmänkestävyydessä on melkoisia eroavuuksia. Syysrukiilla ei sen sijaan edes kolmena kylmänä talvena, 1939—40, 1940—41 ja 1941—42, todettu tässä suhteessa suuria eroavuuksia, huolimatta siitä, että yllämainittujen tutkijoiden mukaan $(1,18,19)$ ruislajikkeillakin eroavuuksia esiintyisi. Keväällä vuonna 1940, jolloin vehnä ja vehnäkokeet olivat Skånessa (Alnarp ja Svalöf) hyvin pahasti kärsineet kylmän vahinkojen vuoksi, näytti siltä kuin osittain samanlaisia vahinkoja esiintyisi myös syysruiskokeissani. Niissä nim. ei todettu pahoja lumihomeen tuhoja. Lumihometta oli vain hiukan siellä täällä muutamissa kuolleissa kasveissa; useimmat niistä näyttivät kylmän turmelemilta. Tarkempi tutkimus kuitenkin osoitti, että nämä »kylmäntuhot» olivat keskinäisessä suhteessa

Taulukko 1. Siemensaastunnan (Fusarium) ja oraiden häviämisen ("kylmänvahingot») välinen suhde eri ruiserissä Svalöfissä 1939-1940 (peittaamaton siemen).

Tab. 1. Korrolationen mellan utsädessmittan ( $F$ us a ri u m) och utgången ("sköldskada") av de olika rågnumven vid Svalöv 1939-40 (obetat utsäde).

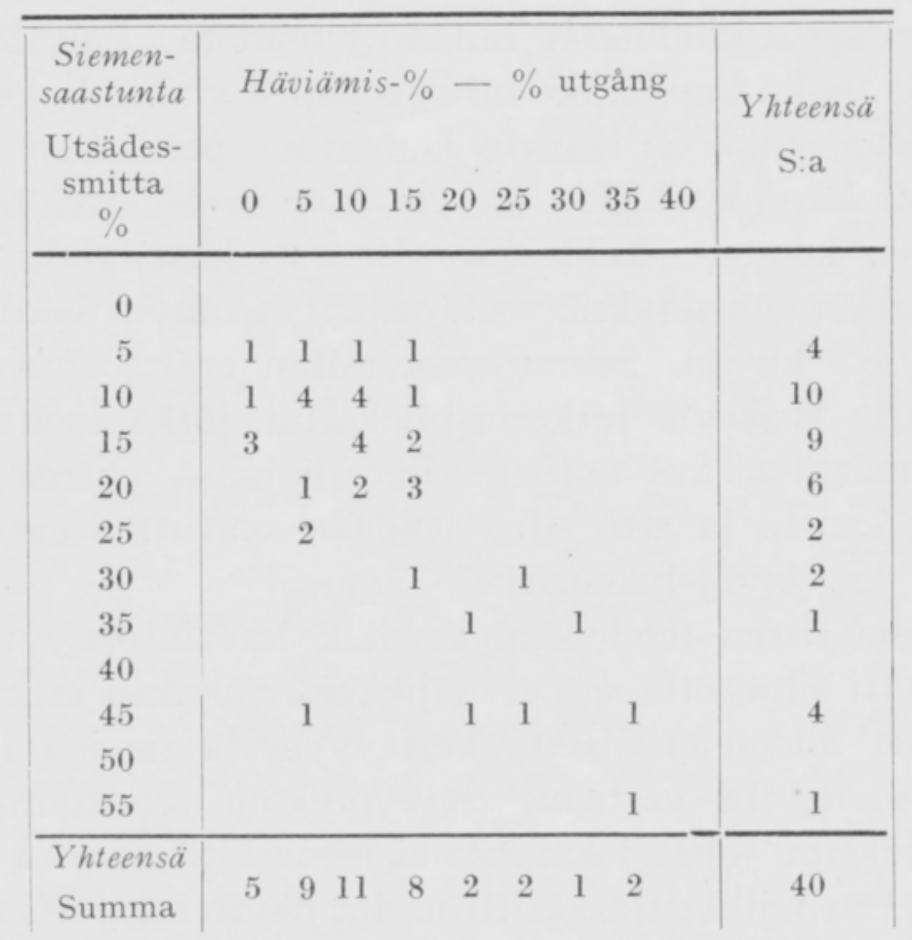


kylvösiemenen laatuun. Tämä selviää taulukosta 1. Siinä nähdään, mikä suhde vallitsi siemenen saastunnan ja oraiden tuhoutumisen välillä Svalöfissä suoritetuissa kokeissa. Taulukon luvuista voidaan melkoisella varmuudella päätellä, että vain sellaiset yksilöt, jotka olivat Fusarium-sienien heikentämiä, kestivät samalla heikommin kylmyyttä. Suhde oli sama, kuuluivatko nämä Åkermanin ja AndersoNin mukaan kylmänkestäviin ja, kuten myöhemmin osoitetaan, Fusariumia vastaan kestäviin lajikkeisiin vai olivatko ne kylmyydelle ja sienille alttiitta lajikkeita. Myös peitatusta siemenestä kehittyneessä kasvustossa esiintyi tietyssä mielessä sama asia, vaikkakaan oraiden kuoleminen ei tällöin ollut yhtä runsasta kuin peittaamattomissa koeruuduissa. Todellisia kylmänvahinkoja ei siis esiintynyt, enkä ole muissakaan tapauksissa koskaan havainnut rukiiden tuhoutumista yksinomaan kylmänvahinkojen vuoksi. Tästä syystä, ennen kuin voidaan tehdä lopullisia päätelmiä tuhoutuneista oraista, jotka näyttävät kylmän turmelemilta, on oltava selvillä siitä, millainen on ollut peittaamattoman siemenen homesieniin saastuminen. Eri vuosina suoritetuissa kokeissa saattavat näin ollen talvehtimisen ja sen seurauksena myös satotuloksien vaihtelut johtua siitä, että siemenen saastuminen Fusarium-sieniin on ollut vaihteleva ja sen vuoksi lajikkeet eri lailla arkoja kylmänvahingoille.

Useissa kokeissani en ole todennut sanottavaa oraiden kuolemista, vaikka siemen oli voimakkaasti fusariumien saastuttamaa ja lajikkeet alttiita näille sienille. Jos sen sijaan olosuhteet talven aikana ovat edulliset Fusarium-sienille, voi oraîden saastuminen olla hyvin voimakasta ja niiden häviäminen runsasta. Tällaisissa tapauksissa kokeet ovat aina tarjonneet hyviä mahdollisuuksia päätelmien teolle eri ruislajikkeiden lumihomeenkestävyydestä. Eri lajikkeiden saastuminen lumihomeeseen ei sellaisenaan sano vielä varsin paljoa, koska lumihometta voi olla myös kestävissä lajikkeissa melko runsaasti. Kestävimmissä lajikkeissa lumihomeen tuhot kuitenkin rajoittuvat usein vain yksityisiin lehtiin, kun taas alttiissa lajikkeissa suurin osa lehdistä ja useimmiten kasvit kokonaan ovat saastuneet. Hävinneiden yksilöiden prosenttimäärät osoittavat näin ollen eri lajikkeiden välisen kestävyyden lumihometta vastaan. Taulukossa 2 nähdään tulokset ruiskokeista Nytorpissa Hälsinglandissa 1943-44. Lajikkeet on jaettu siinä eri ryhmiin siemenen saastumisasteen perusteella. Tulokset osoittavat, että kasvien häviäminen on ollut hyvin erilainen eri lajikkeissa ja lajikeryhmissä. Varsinkin peittaamattomissa kylvöksissä voidaan lajikkeet erottaa selvästi toisistaan sen mukaan, onko niiden häviäminen ollut runsas vai vähäinen. Sama on asian laita myös peittauksen jälkeen, vaikka oraiden häviäminen on tietenkin silloin vähäisempää. Peitatuissa viljoissa on oraiden kuoleminen ollut monissa kokeissa merkityksettömän pieni, mutta toisinaan voi sattua, että peittauksen teho jää heikoksi, jos olosuhteet talven aikana ovat edulliset lumihomeen esiintymiselle. Vaikka siemenen saastunta on silloin lievä tai siemen on kokonaan vapaa saastunnasta, tuhoutuu kasveja runsaasti talven aikana maasta käsin tapahtuvan lumihomesaastunnan vuoksi. Sitä osoittavat tulokset taulukossa 3 .

Ruislajikkeet voidaan lumihomeenkestävyyden mukaan jakaa kahteen ryhmään. Kestäviä ovat suomalaiset lajikkeet Ensi, Oiva, ja Toivo, muista lajikkeista 
Taulukko 2. Siemensaastunnan ja fusariumien tuhojen välinen suhde ja siitä johtuva oraiden häviäminen eri ruislajikkeissa Nytorpissa 1943-44.

Tab. 2. Sambandet mellan utsändessmittan och $F$ us a ri u m-angrepp och den därigenom förorsakade utgàngen hos olika rägsorter vid Nytorp I943-44.

\begin{tabular}{|c|c|c|c|c|c|c|c|}
\hline \multirow[b]{2}{*}{$\begin{array}{l}\text { N:o } \\
\text { N:r }\end{array}$} & \multirow[b]{2}{*}{$\begin{array}{c}\text { Ruislajike } \\
\text { Rågsort }\end{array}$} & \multicolumn{3}{|c|}{$\begin{array}{c}\text { Peittaamaton siemen } \\
\text { Obetat utsäde }\end{array}$} & \multicolumn{3}{|c|}{$\begin{array}{l}\text { Peitattu siemen } \\
\text { Betat utsäde }{ }^{1} \text { ) }\end{array}$} \\
\hline & & $\begin{array}{l}\text { Siemen- } \\
\text { saastunta } \\
\text { Utsädes- } \\
\text { smitta \% }\end{array}$ & $\begin{array}{c}\text { Fusarium- } \\
\text { tuhot } \\
\text { Fusarium- } \\
\text { angrep \% }\end{array}$ & $\begin{array}{c}\text { Häviämis- } \\
\% \text { \% } \\
\text { Utgång } \\
\%\end{array}$ & $\begin{array}{l}\text { Siemen- } \\
\text { saastunta } \\
\text { Utsädes- } \\
\text { smitta \% }\end{array}$ & $\begin{array}{c}\text { Fusarium- } \\
\text { tuhot } \\
\text { Fusarium- } \\
\text { angrep \% }\end{array}$ & $\begin{array}{c}\text { Hävrämis- } \\
\% \\
\text { Utgång } \\
\%\end{array}$ \\
\hline
\end{tabular}

Siemensaastunta yli $50 \%$ — Över $50 \%$ utsädessmitta

\begin{tabular}{|c|c|c|c|c|c|c|c|}
\hline 18 & Oiva $\ldots \ldots \ldots \ldots$ & 80 & 91,0 & 13,9 & 0 & 84,0 & 7,1 \\
\hline 16 & Toivo $\ldots \ldots \ldots$ & 61 & 85,0 & 12,7 & 2 & 66,0 & 4,8 \\
\hline 23 & J. Vaasa II & & & & & & \\
\hline & F. Vasa II $\ldots$. & 65 & 99,0 & 88,0 & 0 & 87,0 & 47,8 \\
\hline 5 & Kungs II ........ & 58 & 100,0 & 92,8 & 0 & 75,0 & 34,9 \\
\hline \multicolumn{8}{|c|}{ Siemensaastunta $40-50 \%-40-50 \%$ utsädessmitta } \\
\hline 24 & Sangaste....$\cdots$ : & 45 & 93,0 & 22,8 & 0 & 48,0 & 3,4 \\
\hline 15 & Toivo $\quad \ldots \ldots \ldots$. & 43 & 88,0 & 25,2 & 2 & 47,0 & 3,7 \\
\hline 3 & Stål $\ldots \ldots \ldots \ldots$ & 46 & 90,0 & 89,9 & 0 & 53,0 & 18,9 \\
\hline 7 & Stål $\ldots \ldots \ldots \ldots$ & 45 & 100,0 & 89,8 & 0 & 73,0 & 40,8 \\
\hline \multicolumn{8}{|c|}{ Siemensaastunta $30-40 \%-30-40 \%$ utsädessmitta } \\
\hline 14 & Ensi $\ldots \ldots \ldots \ldots$ & 35 & 57,0 & 10,5 & 0 & 18,0 & nimeksi \\
\hline 2 & Kungs II ....... & 34 & 99,0 & 89,3 & 0 & 43,0 & 14,9 \\
\hline 4 & Kungs II $\ldots \ldots$. & 34 & 99,0 & 86,3 & 0 & 52,0 & 12,6 \\
\hline 25 & Agro $\ldots \ldots \ldots \ldots$ & 36 & 100,0 & 85,7 & 0 & 68,0 & 26,1 \\
\hline \multicolumn{8}{|c|}{ Siemensaastunta $20-30 \%-20-30 \%$ utsädessmitta } \\
\hline 17 & Oiva $\ldots \ldots \ldots \ldots$ & 22 & 75,0 & 4,2 & 0 & 24,0 & nimeksi \\
\hline 11 & Gotland I . . . . . . . & 23 & 48,0 & 0,2 & 1 & 43,0 & 4,4 \\
\hline 27 & Gotland II $\ldots .$. & 24 & 74,0 & 21,6 & 0 & 39,0 & 0,7 \\
\hline 13 & J. Vaasa II ..... & 24 & 94,0 & 65,7 & 0 & 45,0 & 10,3 \\
\hline 20 & Malm . . . . . . & 27 & 51,0 & 19,7 & 0 & 46,0 & 15,5 \\
\hline \multicolumn{8}{|c|}{ Siemensaastunta IO- $20 \%-10-20 \%$ utsädessmitta } \\
\hline 8 & Sangaste..... & 15 & 50,0 & 2,4 & 0 & 11,0 & 0,7 \\
\hline 28 & Björn $\quad \ldots \ldots \ldots$ & 17 & 31,0 & 2,3 & 0 & 9,0 & 0,6 \\
\hline 12 & J. Vaasa II ..... & 13 & 42,0 & 5,8 & 0 & 21,0 & 2,3 \\
\hline 1 & J. Vaasa II ..... & 14 & 82,0 & 57,8 & 0 & 30,0 & 3,9 \\
\hline 9 & Petkus I ...... & 17 & 80,0 & 43,4 & 2 & 25,0 & 4,5 \\
\hline \multicolumn{8}{|c|}{ Siemensaastunta $0-10 \%-0-10 \%$ utsädessmitta } \\
\hline 26 & Norrbotten ..... & 1 & 3,0 & 0,0 & 0 & nimeksi & 0,0 \\
\hline 19 & Sangaste $\ldots . .$. & 7 & 52,0 & 4,6 & 0 & 11,0 & nimeksi \\
\hline 21 & Björn $\quad \ldots \ldots \ldots$ & 4 & 34,0 & 5,0 & 0 & 13,0 & nimeksi \\
\hline 10 & Petkus II ....... & 9 & 40,0 & 11,9 & 0 & 12,0 & 1,1 \\
\hline 6 & Kungs II ....... & 7 & 87,0 & 40,3 & 0 & 36,0 & 4,6 \\
\hline
\end{tabular}

1) nimeksi $=$ spår. 
Taulukko 3. Siemensaastunnan ja oraiden häviämisen välinen suhde eri ruislajikkeissa Vassbossa, Ornäsissa, 1939-1940.

Tab. 3. Sambandet mellan utsädessmittan och utgången hos olika rågsorter vid Vassbo, Ornäs, 1939-40.

\begin{tabular}{|c|c|c|c|c|c|}
\hline \multirow{2}{*}{$\begin{array}{l}N: 0 \\
N: r\end{array}$} & \multirow{2}{*}{$\begin{array}{c}\text { Ruislajike } \\
\text { Rågsort }\end{array}$} & \multicolumn{2}{|c|}{$\begin{array}{l}\text { Peittamaton siemen } \\
\text { Obetat utsäde }\end{array}$} & \multicolumn{2}{|c|}{$\begin{array}{l}\text { Peitattu siemen } \\
\text { Betat utsäde }\end{array}$} \\
\hline & & $\begin{array}{l}\text { Siemen- } \\
\text { saastunta } \\
\text { Utsädes- } \\
\text { smitta \% }\end{array}$ & $\begin{array}{c}\text { Häviämis- } \\
\% \% \\
\text { Utgång } \\
\%\end{array}$ & $\begin{array}{l}\text { Siemen- } \\
\text { saastunta } \\
\text { Utsädes- } \\
\text { smitta \% }\end{array}$ & $\begin{array}{c}\text { Häviämis- } \\
\text { \% } \\
\text { Utgång } \\
\%\end{array}$ \\
\hline
\end{tabular}

Siemensaastunta yli $40 \%$ - Över $40 \%$ utsädessmitta

\begin{tabular}{r|l|l|l|l|l}
6 & Oiva $\ldots \ldots \ldots \ldots$ & 44 & 44 & 0 & 25 \\
23 & Sangaste $\ldots \ldots \ldots$ & 43 & 51 & 1 & 41 \\
17 & Kungs $\ldots \ldots \ldots \ldots$ & 53 & 83 & 1 & 85 \\
13 & Kungs $\ldots \ldots \ldots \ldots$ & 42 & 83 & 3 & 81 \\
9 & Stål $\ldots \ldots \ldots \ldots$. & 40 & 85 & 0 & 80
\end{tabular}

Siemensaastunta $30-40 \%-30-40 \%$ utsädessmitta

\begin{tabular}{r|l|l|l|l|l}
15 & Malm ......... & 31 & 79 & 5 & 78 \\
7 & Stjärn . . . . . & 33 & 87 & 1 & 76
\end{tabular}

Siemensaastunta $20-30 \%-20-30 \%$ utsädessmitta

\begin{tabular}{l|l|l|l|l|l|l}
26 & Upland $\ldots \ldots \ldots \ldots$ & 20 & 24 & 1 & 15 \\
14 & Kungs. ......... & 25 & 83 & 0 & 85 \\
21 & Malm . . . . . . . & 27 & 72 & 2 & 76
\end{tabular}

Siemensaastunta $10-20 \%-10-20 \%$ utsädessmitta

\begin{tabular}{l|l|l|l|l|l}
25 & Norrbotten ...... & 15 & 10 & 1 & 34
\end{tabular}

\begin{tabular}{l|l|l|l|l|l|}
1 & Oiva $\ldots \ldots \ldots \ldots \ldots$ & 14 & 27 & 3 & 17
\end{tabular}

\begin{tabular}{l|l|l|l|l|l}
3 & Oiva $\ldots \ldots \ldots \ldots$ & 16 & 20 & 5 & 13
\end{tabular}

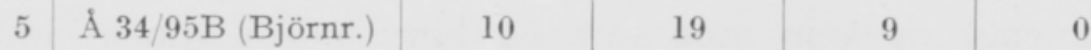

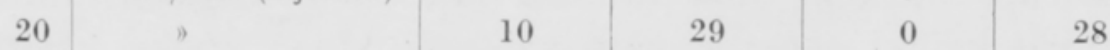

\begin{tabular}{|l|l|l|l|l|l|}
31 & Sangaste $\ldots \ldots \ldots$ & 10 & 12 & 2 & 13
\end{tabular}

\begin{tabular}{|l|l|l|l|l|l|}
36 & Kungs II $\ldots \ldots .$. & 10 & 43 & 3 & 50
\end{tabular}

\begin{tabular}{|l|l|l|l|l|l|l|}
\hline 8 & Kungs I & $\ldots \ldots \ldots$ & 18 & 83 & 1 & 73
\end{tabular}

\begin{tabular}{l|l|l|l|l|l|}
\hline 16 & J. Vaasa II &
\end{tabular}

\begin{tabular}{|l|l|l|l|l|l} 
F. Vasa II & $\ldots$ & 15 & 78 & 2 & 78
\end{tabular}

\begin{tabular}{|l|l|l|l|l|}
\hline J. Vaasa II _.... & 17 & 74 & 0 & 71
\end{tabular}

\begin{tabular}{|l|l|l|l|l|l|l|}
12 & Stål $\ldots \ldots \ldots \ldots \ldots$ & 10 & 48 & 0 & 46
\end{tabular}

\begin{tabular}{|l|l|l|l|l|l|l|}
33 & Stål $\ldots \ldots \ldots \ldots$ & 12 & 43 & 1 & 57
\end{tabular}

\begin{tabular}{|l|l|l|l|l|l|}
28 & Petkus II . . . . . & 16 & 59 & 0 & 70
\end{tabular}

\begin{tabular}{|l|l|l|l|l|l|l|}
\hline 10 & Agro $\ldots \ldots \ldots . . .6$ & 10 & 81 & 3 & 75
\end{tabular}

Siemensaastunta $0-10 \%-0-10 \%$ utsädessmitta

\begin{tabular}{|c|c|c|c|}
\hline Oiva $\ldots \ldots \ldots \ldots$ & 4 & 9 & 0 \\
\hline Toivo $\ldots \ldots \ldots$. & 5 & 11 & 0 \\
\hline Sangaste...$\ldots$. & 6 & 11 & 2 \\
\hline Stål $\ldots \ldots \ldots \ldots \ldots$ & 3 & 51 & 0 \\
\hline Stål $\ldots . . . \ldots . .$. & 4 & 47 & 0 \\
\hline Stål $\ldots \ldots \ldots \ldots$ & 9 & 51 & 1 \\
\hline Kungs $\ldots \ldots \ldots$. & 8 & 44 & 3 \\
\hline J. Vaasa II $\ldots . .$. & 4 & 36 & 0 \\
\hline J. Vaasa II $\ldots . .$. & 8 & 70 & 1 \\
\hline Petkus II ....... & 9 & 60 & 1 \\
\hline Petkus I $\ldots . .$. . & 7 & 34 & 1 \\
\hline Självbindare $\ldots$. & 9 & 57 & 2 \\
\hline & 9 & 40 & 2 \\
\hline
\end{tabular}


Sangaste, Björn, joukko maatiaislajikkeita, niistä ennen muuta Norrbotten, sekä juhannusrukiit. Lumihomeelle alttiita ovat mım. Jalostettu Vaasa II, Teräs, Kungs, Malm ja Petkus. Kuten taulukosta 2 ja 3 nähdään, voi myös silloin, kun siemenen saastuminen on lievää, alttiissa lajikkeissa tuhoutua runsaasti oraita, olosuhteiden ollessa edullisia lumihomeen esiintymiselle. Kestävillä lajikkeilla oraiden tuhoutuminen jää sen sijaan suhteellisen vähäiseksi varsinkin peittauksen ansiosta, huolimatta siitä, että siemen on voimakkaasti saastunut ja olosuhteet suotuisat lumihomeen vahingoille.

Myös nurmiheinien suhtautumisessa lumihomeeseen voi toisinaan olla suuria eroavuuksia, vaikka niihin nähden on ehkä vaikeata päätellä, mikä osuus siemenen Fusarium-saastunnalla on ollut kasvien tuhoutumiseen talven aikana. Esitän tästä vain yhden esimerkin nurminadalla Torstassa Jämtlandissa v. 1944—45 suoritetusta kokeesta (taul. 4), joka osoittaa, että eri kantojen kestävyydessä lumihometta vastaan on todettavissa selviä eroavuuksia.

\section{Typhula- ja Sclerotinia-sienien merkitys.}

Eri syysruislajikkeiden ja nurmiheinien kestävyydessä muita talvehtimissieniä, Typhula-lajeja ja Sclerotinia borealista vastaan on epäilemättä suuria eroavuuksia. Nämä sienet eivät saastuta siementä, minkä vuoksi edellytykset saastumiselle ovat osittain aivan toiset kuin lumihomeella. Syysviljoissa ei ole aina helppoa määrittää lajikkeiden kestävyyttä näitä sieniä vastaan, sillä olosuhteet, jotka suosivat Typhula- ja Sclerotinia-sienien esiintymistä, ovat otolliset myös lumihomeelle, joten oraissa ilmenee melkein aina samalla lumihomeen aiheuttamia tappioita. Toisinaan esiintyvät kaikki sienet samanaikaisesti, minkä vuoksi yksityiskohtaisia tietoja eri sienilajien vahingoista on vaikea saada, varsinkin kun kaikilla näillä

Taulukko 4. Lumihomeesta aiheutunut kasvien tuhoutuminen nurminadassa 1. vuoden nurmessa talvella 1944-45 Ruotsin kylvösiemenyhdistyksen haaraosastossa Torstassa, Jämtlandissa.

Tab. 4. Utgång på grund av snömögel hos ängssvingel $i$ 1-sta års vall vintern $1944-45$ vid Sveriges utsädesförenings filial Torsta, Jämtland.

\begin{tabular}{|c|c|c|}
\hline $\mathrm{N}: \mathrm{O}$ & Kanta & Häviämis- $\%$ \\
\hline$N: r$ & Stam & \% Utgång \\
\hline \multirow[t]{2}{*}{41} & Svalöfin myöhäinen & \\
\hline & Svalövs sena $\ldots \ldots \ldots \ldots$ & 15,0 \\
\hline \multirow[t]{2}{*}{42} & Svalöfin aikainen & \\
\hline & Svalövs tidiga $\ldots \ldots \ldots \ldots$ & 71,3 \\
\hline 43 & Fepra $\quad \ldots \ldots \ldots \ldots \ldots$ & 61,3 \\
\hline 44 & Mimer $\quad \ldots \ldots \ldots \ldots \ldots$ & 75,0 \\
\hline 45 & Bottnia $\quad \ldots \ldots \ldots \ldots$ & 12,5 \\
\hline 46 & " Luleåsta f. Luleå & 20,0 \\
\hline 47 & $\AA 1341$. & 7,5 \\
\hline 48 & $\AA 1317$. & 5,0 \\
\hline 49 & J. $29 \ddot{A} \ldots \ldots \ldots \ldots \ldots$ & 22,5 \\
\hline 50 & $\mathrm{~J} .4 \ddot{\mathrm{A}} \quad \ldots \ldots \ldots \ldots \ldots$ & 22,5 \\
\hline
\end{tabular}


Taulukko 5. Typhula borealisen aiheuttama tuho eri ruislajikkeissa Torstassa $1944-45$ suoritetussa kokeessa.

Tab. 5. Utgång genom angrepp av $T$ yph $u l a$ bore a lis på olika rågsorter $i$ försök vid Torsta $1944-45$.

\begin{tabular}{|c|c|c|c|}
\hline \multirow{2}{*}{$\begin{array}{l}N: 0 \\
N: r\end{array}$} & \multirow{2}{*}{$\begin{array}{c}\text { Ruislajike } \\
\text { Rågsort }\end{array}$} & \multicolumn{2}{|c|}{ Häviämis- \% — \% Utgång 1 ) } \\
\hline & & $\begin{array}{c}\text { Peittamaton } \\
\text { Obetat }\end{array}$ & $\begin{array}{c}\text { Peittattu } \\
\text { Betat }\end{array}$ \\
\hline 26 & Norrbotten $\ldots \ldots \ldots \ldots$ & nimeksi & 0,7 \\
\hline 13 & Ensi $\ldots \ldots \ldots \ldots \ldots \ldots$ & nimeksi & nimeksi \\
\hline 12 & Pekka $\ldots \ldots \ldots \ldots \ldots$ & nimeksi & nimeksi \\
\hline 16 & Toivo $\ldots \ldots \ldots \ldots \ldots$ & nimeksi & nimeksi \\
\hline 17 & $" \quad \ldots \ldots \ldots \ldots \ldots$ & nimeksi & 2,7 \\
\hline 14 & Oiva $\ldots \ldots \ldots \ldots \ldots \ldots$ & nimeksi & 8,8 \\
\hline 15 & $" \quad \ldots \ldots \ldots \ldots \ldots \ldots$ & nimeksi & 10,7 \\
\hline 11 & Juhannusruis & & \\
\hline & Midsommarråg $\quad \ldots \ldots \ldots$ & 4,1 & 12,3 \\
\hline 22 & Sangaste $\ldots \ldots \ldots \ldots$ & 27,8 & 41,6 \\
\hline 3 & $" \quad \ldots \ldots \ldots \ldots \ldots$ & 45,7 & 19,2 \\
\hline 19 & $\ldots \ldots \ldots \ldots \ldots$ & 54,6 & 41,6 \\
\hline 5 & $\ldots \ldots \ldots \ldots$ & 36,8 & 30,2 \\
\hline 2 & Björn $\ldots \ldots \ldots \ldots \ldots$ & 79,0 & 30,5 \\
\hline 8 & $\ldots \ldots \ldots \ldots \ldots$ & 44,0 & 40,5 \\
\hline 6 & $\ldots \ldots \ldots \ldots \ldots$ & 34,6 & 33,4 \\
\hline 10 & Gotland $\ldots \ldots \ldots \ldots$ & 47,8 & 44,9 \\
\hline 18 & J. Vaasa II $\ldots \ldots \ldots \ldots$ & & \\
\hline & F. Vasa II $\ldots \ldots \ldots \ldots$ & nimeksi & 92,3 \\
\hline 9 & $" \quad($ Offer $) \ldots \ldots$ & 89,7 & 82,3 \\
\hline 4 & $" \quad \ldots \ldots \ldots \ldots$ & 95,2 & 95,3 \\
\hline 27 & $" \quad \ldots \ldots \ldots \ldots$ & 96,6 & 98,0 \\
\hline 20 & Kungs II $\ldots \ldots \ldots \ldots \ldots$ & 100,0 & 95,4 \\
\hline 21 & $" \quad, \quad \ldots \ldots \ldots \ldots \ldots$ & 100,0 & 89,1 \\
\hline 25 & $" \quad " \quad \ldots \ldots \ldots \ldots \ldots$ & 93,3 & 92,2 \\
\hline 23 & Stål $\ldots \ldots \ldots \ldots \ldots \ldots$ & 94,9 & 92,1 \\
\hline 7 & $" \quad \ldots \ldots \ldots \ldots \ldots \ldots$ & 96,1 & 95,8 \\
\hline 1 & Malm $\ldots \ldots \ldots \ldots \ldots$ & 96,7 & 88,8 \\
\hline 24 & Petkus $\ldots \ldots \ldots \ldots \ldots$ & 98,1 & 96,8 \\
\hline
\end{tabular}

sienillä on tietynlainen antagonistinen vaikutus toistensa suhteen siten, että yksilö, joka on jonkin sienen saastuttama, säilyy toisen sienen tuhoilta. Kokeista voidaan tästä huolimatta tehdä koko joukko päätelmiä lajikkeiden kestävyydestä eri sienitauteja vastaan.

Kun otamme ensin käsiteltäväksi Typhula-suvun, on todettava, että viljoissa samoin kuin nurmiheinissä esiintyy useita Typhula-lajeja, ennen muuta $T$. itoana ja $T$. borealis, näistä viimeksimainittu tavallisesti pahimpana tuhonaiheuttajana. T. borealisen esiintymisrunsaus on eri vuosina vaihteleva, minkä vuoksi sen aiheuttamat tuhot myös suuresti vaihtelevat. Tässä ei ole tilaisuutta kuvata lähemmin 
Taulukko 6. Typhula borealisen aiheuttamat tuhot timoteikokeessa (1. vuoden nurmi) Torstassa 1944-45.

Tab. 6. Timotejförsök (1-sta års) med utgång förorsakad av T y p h u la borealis vid Torsta $1944-45$.

\begin{tabular}{|c|c|c|c|}
\hline $\begin{array}{l}N: 0 \\
N: r\end{array}$ & Kanta - Stam & $\begin{array}{c}\text { Alkuperä } \\
\text { Härkomst }\end{array}$ & $\begin{array}{c}\text { Häviämis- } \\
\text { \% } \\
\text { \% Utgång }\end{array}$ \\
\hline & I & & \\
\hline 20 & Gloria $\ldots \ldots \ldots$ & Skåne & 69 \\
\hline 21 & " Luleå 2: I & Norrbotten & 56 \\
\hline 22 & Kempe II $\quad \ldots \ldots$ & Skåne & 44 \\
\hline 23 & Bore $I \ldots \ldots \ldots$. & ") & 51 \\
\hline 24 & Bore II $\ldots \ldots \ldots$ & ") & 76 \\
\hline 25 & Bottnia $\quad \ldots \ldots \ldots$ & ") & 23 \\
\hline 26 & Hammenhög $\ldots$. & " & 56 \\
\hline 27 & J. $0824 \ldots \ldots \ldots$ & Jämtland & $3 I$ \\
\hline 28 & J. 0824 , valittu & & \\
\hline & urval & a & 33 \\
\hline 29 & J. $0834 \ldots \ldots \ldots$ & , & 41 \\
\hline 30 & U.D. 4: I $\ldots \ldots \ldots$ & ? & 55 \\
\hline & II & & \\
\hline 31 & Gloria $\ldots \ldots \ldots$ & Skåne & 73 \\
\hline 32 & Sv. $0812 \quad \ldots \ldots \ldots$ & " & 75 \\
\hline 33 & , $\quad 0825 \quad \ldots \ldots \ldots$ & " & 65 \\
\hline 34 & \# $\quad 0826 \quad \ldots \ldots \ldots$ & ") & 61 \\
\hline 35 & " $\quad 0830 \quad \ldots \ldots \ldots$ & ) & 53 \\
\hline 36 & Bottnia Bol. . . . . & s & 34 \\
\hline 37 & , $\quad 41 / 96 \ldots$ & Norrbotten & 28 \\
\hline 38 & , $\mathrm{KV} \mathrm{B} \mathrm{A}$ & i) & 25 \\
\hline 39 & J. $0824 \ldots \ldots \ldots$ & Jämtland & 34 \\
\hline 40 & J. $0834 \ldots \ldots \ldots$ & ") & 56 \\
\hline
\end{tabular}

näitä sieniä. Esitettäköön vain muutamia kuvia T. borealisesta. Kuva 1 osoittaa, miltä sienen vahingot näyttävät timotein siemenviljelyksillä, kuvassa 2 nähdään sienen tappamia kasveja keväällä ja kuvassa 3 sienen itiöemiä syksyllä, jolla asteella itiöt saastuttavat syysviljoja ja nurmiheiniä.

Esimerkin syysruislajikkeiden kestävyydestä $T$. borealista vastaan osoittaa koe taulukossa 5. Saastuminen lumihomeeseen oli tässä kokeessa samanaıkaisesti hyvin voimakas. Taulukossa esitetyissä luvuissa on otettu huomioon vain ne kasvit, jotka ovat tuhoutuneet $T$. borealisen vuoksi. Mainittakoon tässä yhteydessä, että jos lumihome aiheuttaa suurta vahinkoa oraissa, saadaan tietystikin hyvin epävarmoja lukuja Typhula-sienen tuhoista; jossakin määrin myös silloin kun siemen on ollut peittaamatonta.

Syysvehnän alttius Typhula borealisen suhteen on suurempi kuin syysrukiin. Varmaan myös eri lajikkeiden kestävyydessä on eroavuuksia.

Nurmiheinillä ovat kestävyyseroavuudet $T$. borealista vastaan hyvin selvät, kuten esimerkiksi otetusta kokeesta taulukossa 6 nähdään. Tulokset osoittavat, 
Taulukko 7. Sclerotinia borealisen aiheuttama oraiden häviäminen ruiskokeissa Ruotsin kylvösiemenyhdistyksen haaraosastossa Torstassa, Jämtlandissa 1941—42.

Tab. 7. Utgång genom angrepp av Sclerotinia borealis i rågförsök vid Sveriges Utsädesförenings Filial vid Torsta, Jämtland 1941-42.

\begin{tabular}{|c|c|c|c|}
\hline $\begin{array}{l}\mathrm{N}: 0 \\
\mathrm{~N}: \mathrm{r}\end{array}$ & Ruislajike - Rågsort & $\begin{array}{l}\text { Alkuperä } \\
\text { Härkomst }\end{array}$ & $\begin{array}{c}\text { Häviämis- } \\
\% \\
\% \text { Utgång }\end{array}$ \\
\hline & I & & . \\
\hline 1 & 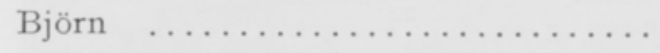 & Svalöf & 45 \\
\hline 2 & Norrbotten (Unbyn) $\ldots \ldots \ldots \ldots \ldots$ & Norrbotten & 42 \\
\hline 3 & J. Vaasa II & & \\
\hline & För. Vasa II $\ldots \ldots \ldots \ldots \ldots \ldots \ldots$ & Svalöf & 83 \\
\hline 5 & $\begin{array}{l}\text { Linje ur För. Vasa I } \ldots \ldots \ldots \ldots \ldots \ldots \\
\text { Linja Östgöta gråråg-rukiista }\end{array}$ & D & 76 \\
\hline 6 & $\begin{array}{l}\text { Linje ur Östgöta gråråg } \ldots \ldots \ldots \ldots \ldots \\
\text { Sv. } 38 / 66 \text {, Malm } \times \text { J. Vaasa II }\end{array}$ & ) & 89 \\
\hline 7 & $\begin{aligned} & \text { Malm } \times \text { För. Vasa II } \quad \ldots \ldots \\
\text { Sv. } 38 / 28, & \text { Malm } \times \text { suomal. ruis } \\
& \text { Malm } \times \text { Finsk råg } \quad \ldots \ldots \ldots\end{aligned}$ & ") & 90 \\
\hline 8 & $\begin{array}{c}\text { Sangaste } \ldots \ldots \ldots \ldots \ldots \ldots \ldots \ldots \\
\text { II }\end{array}$ & ") & 47 \\
\hline 9 & 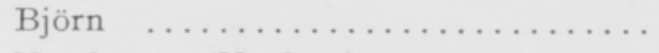 & Svalöf & 66 \\
\hline 10 & Norrbotten (Ungbyn) $\quad \ldots \ldots \ldots \ldots \ldots$ & Norrbotten & $5^{8}$ \\
\hline 11 & J. Vaasa II & anc & \\
\hline 12 & $\begin{array}{l}\text { För Vasa II } \ldots \ldots \ldots \ldots \ldots \ldots \ldots \ldots \ldots \\
\AA \quad 34 / 45, \text { J. Vaasa } \times \text { Härmä }\end{array}$ & Svalöf & 90 \\
\hline 13 & $\begin{array}{l}\AA 34 / 48, \\
\quad \text { Jör. Vaasa } \times \text { Härmä Vasa } \times \text { Härmä }\end{array}$ & Angermanland & 43 \\
\hline 14 & A $34 / 54$, J. Vaasa $\times$ Härmä & & 40 \\
\hline 15 & $\begin{array}{c}\text { För. Vasa } \times \text { Härmä } \quad \ldots \ldots \ldots \\
\AA 34 / 67 \text {, suom. Vaasa-ruis } \times \text { J. Vasa II }\end{array}$ & 1) & $5^{I}$ \\
\hline 16 & $\begin{array}{l}\text { Finsk Vasaråg } \times \text { För. Vasa II } \\
\text { J. 37/15, Malm } \times \text { J. Vaasa II }\end{array}$ & 1) & 45 \\
\hline & " Malm $\times$ För. Vasa II ...... & Jämtland & 87 \\
\hline
\end{tabular}

että kahdessa Ruotsin kylvösiemenyhdistyksen Jämtlandin haaraosastossa suoritetussa timoteikokeessa eräät pohjoisista osista maata peräisin olevat kannat olivat huomattavasti vähemmän Typhulan saastuttamia kuin eteläiset kannat.

Eri syysvehnälajikkeiden suhtautumisessa Typhula itoana-sieneen on myös eroavuuksia. Sitä osoittaa syysvehnällä suoritettu lajike- ja kylvöaikakoe, johon myöhemmin palataan (taul. 10). Tämä sieni ei ole yleensä niinä vuosina, joina tutkimus on suoritettu, esiintynyt pahana tuhonaiheuttajana, minkä vuoksi ei myöskään ole saatu tarkempia tietoja eri lajikkeiden kestävyydestä sitä vastaan.

Sclerotinia borealis, jonka levinneisyys ja tuhot suuresti vaihtelevat samalla tavoin kuin Typhula-lajienkin, voi aiheuttaa joinakin vuosina suuria vahinkoja pohjoisosissa maata. Sieni esiintyy Ruotsissa Norrlandista Taalainmaahan ja 


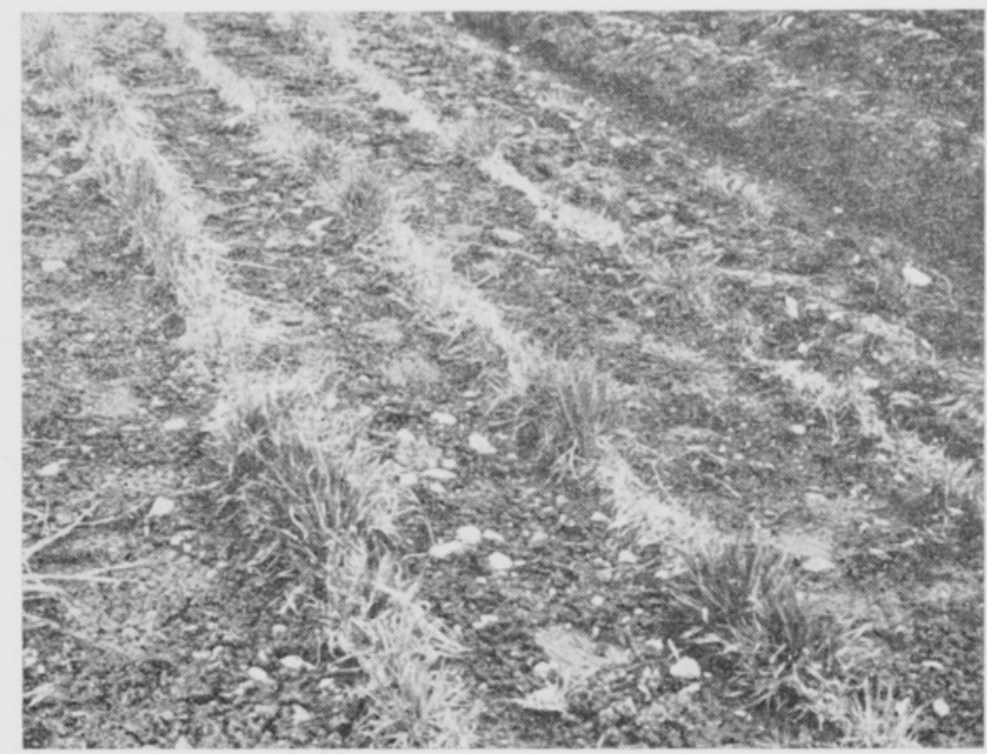

Foto H. Ekstrand.

Kuva 1. Typhula borealisen vahingot 1. vuoden timotein siemenviljelyksessä Ruotsin kylvösiemenyhdistyksen haaraosastossa Torstassa, Jämtlandissa keväällä 1946.

Fig. 1. Skador av $T$ y ph u la bor e a lis $i$ fröodlingar (1-sta års) av timotej, Sveriges Utsädesförenings filial vid Torsta, Jämtland våren 1946.

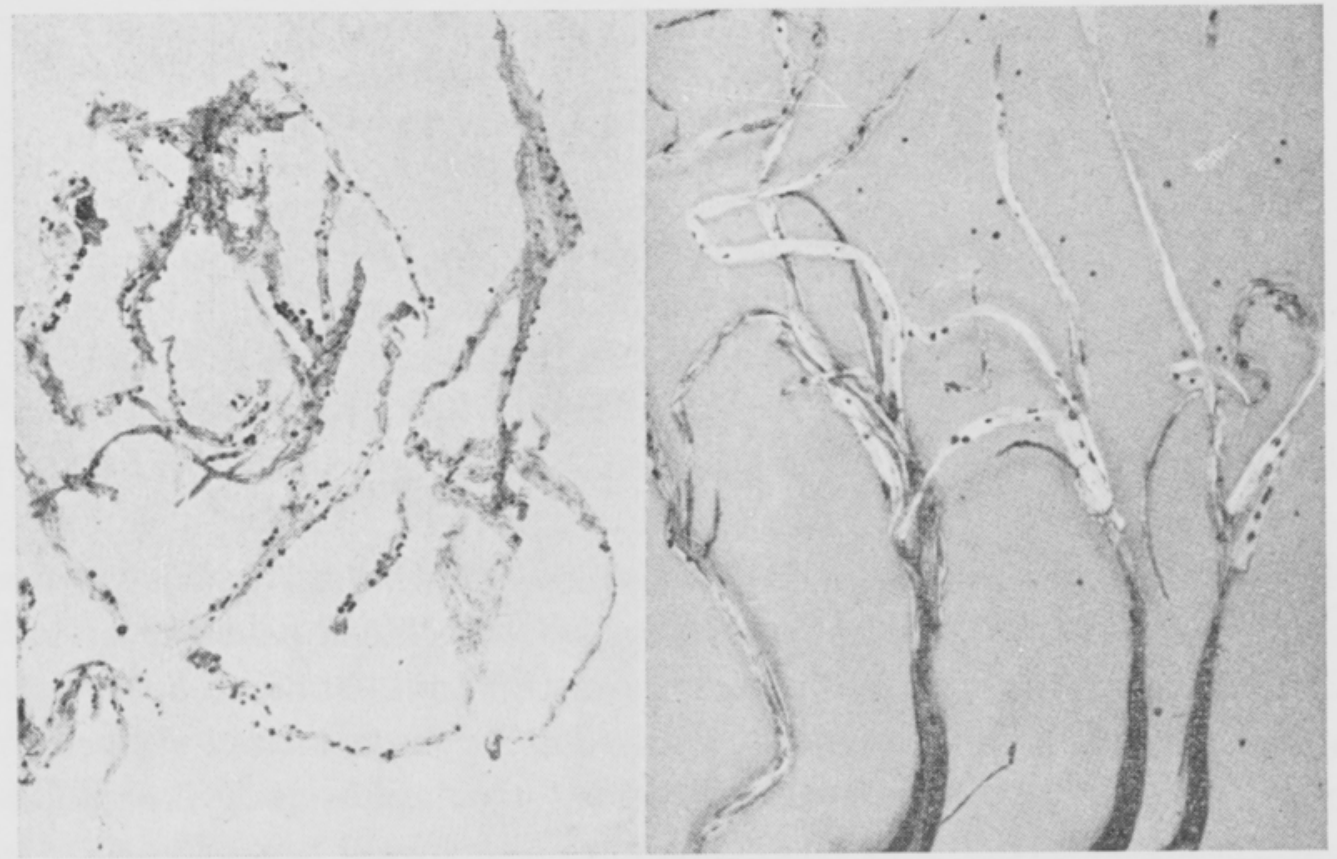

Foto H. Ekstrand.

Kuva 2. Typhula borealis. Vasemmalla, sklerotioita kuolleissa rukiin oraissa; oikealla, sklerotioita vanhoissa timoteikasveissa.

Fig. 2. Ty phula bore a lis. Till vänster, sklerotier på döda rågplantor; till höger, sklerotier på äldre timotejplantor. 


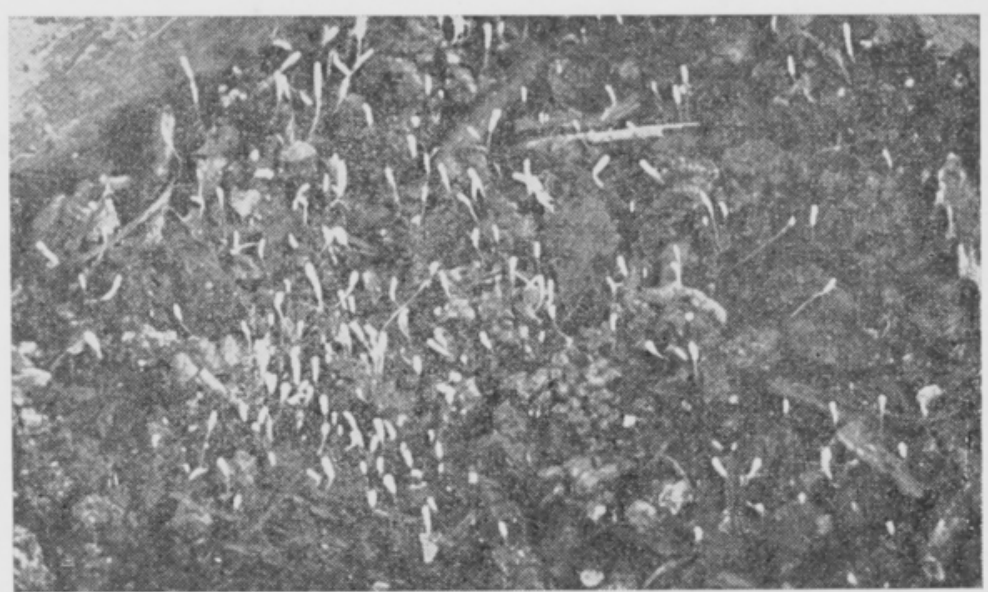

Foto H. EKSTRAND.

Kuva 3. Typhula borealisen itiöemiä.

Fig. 3. Typhula borealis, fruktkroppar.

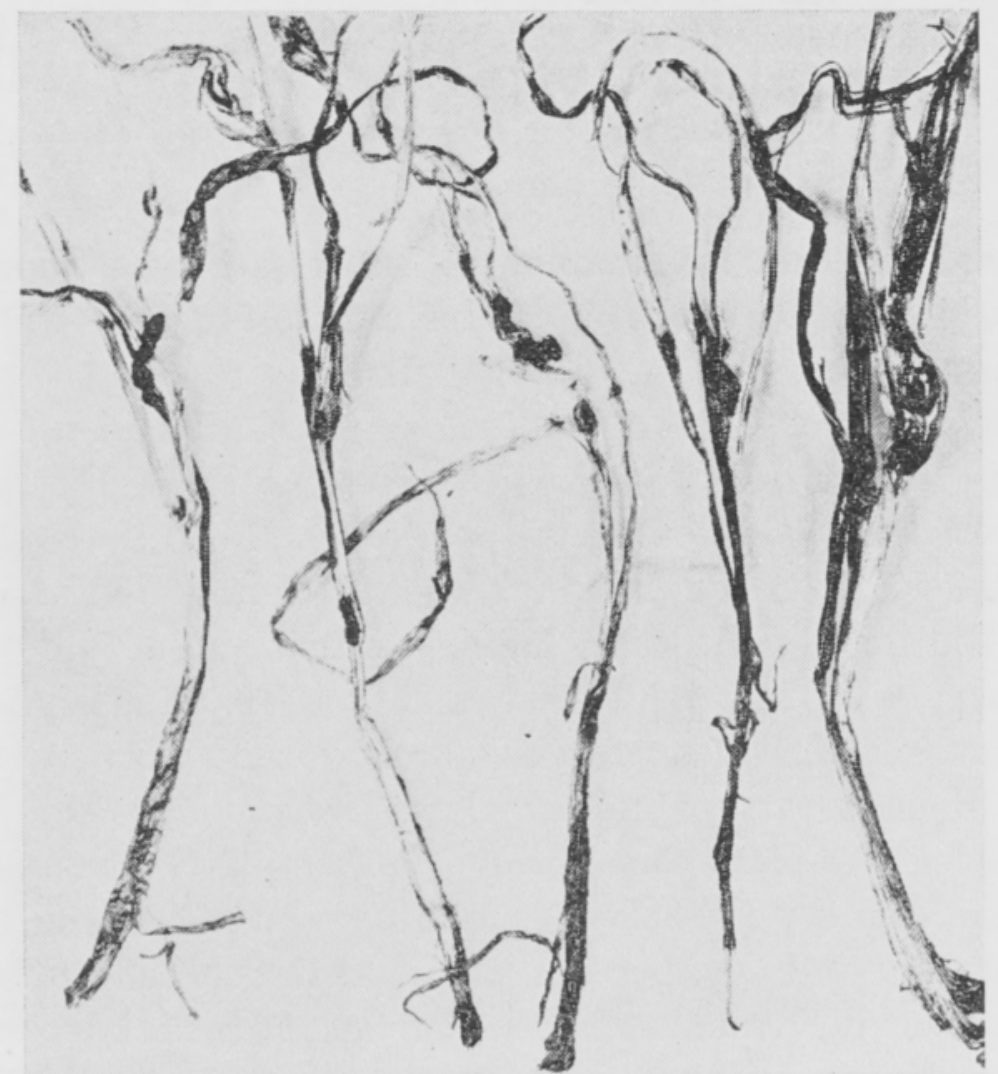

Foto H. EKSTRAND.

Kuva 4. Sclerotinia borealis, sklerotioita vanhoissa timoteikasveissa . Fig. 4. Sclerotinia borealis, sklerotier påäldre timotejplantor. 
Taulukko 8. Sclerotinia borealisen aiheuttama kasvien tuhoutuminen aronatakokeissa (1. vuoden nurmi) Ruotsin kylvösiemenyhdistyksen haaraosastossa Porsögårdenissa 1941—42.

Tab. 8. Utgång genom angreppav Sclerot in i a bor e a lis i försök med rödsvingel (1-sta års) vid Sveriges Utsädesförenings filial vid Porsögården 1941-42.

\begin{tabular}{|c|c|c|c|}
\hline $\begin{array}{l}N: 0 \\
N: r\end{array}$ & $\begin{array}{l}\text { Kanta } \\
\text { Stam }\end{array}$ & $\begin{array}{c}\text { Alkuperä } \\
\text { Härkomst }\end{array}$ & $\begin{array}{c}\text { Häviämis- } \\
\% \\
\% \text { Utgång }\end{array}$ \\
\hline & I & & . \\
\hline 121 & Viking $\ldots$. & Skåne & 93 \\
\hline 122 & $\Rightarrow \quad \ldots \ldots$ & Luleå & 82 \\
\hline 123 & Reptans... & Skåne & 84 \\
\hline 124 & $\operatorname{Rex} \ldots \ldots$ & ) & 90 \\
\hline 125 & L $34 / 2 b \quad \ldots$ & Luleå & 35 \\
\hline 126 & L $34 / 4 \mathrm{~b} \quad \ldots$ & ) & $2 I$ \\
\hline 127 & L $34 / 12 \quad \ldots$ & B & 26 \\
\hline 128 & $\begin{array}{c}\text { L } 34 / 34 \quad \cdots \\
\text { II }\end{array}$ & ) & I6 \\
\hline 129 & Viking $\ldots$. & Skåne & 85 \\
\hline 130 & L $34 / 37 \quad \ldots$ & Luleå & 24 \\
\hline 131 & L $34 / 50 \mathrm{a} \quad \ldots$ & ) & $I I$ \\
\hline 132 & L $34 / 57 \quad \ldots$ & s) & $2 I$ \\
\hline 133 & L $34 / 59 \quad \ldots$ & , & 25 \\
\hline 134 & Lanker .... & Norrbotten & 26 \\
\hline
\end{tabular}

Gästriklandiin saakka. Sitä tavataan myös suuressa osassa Suomea. Kuvassa 4 nähdään sieni pahka-asteellaan keväällä, kuvassa 5 sen itiöemiä syksyllä ja kuvassa 6 sienen aiheuttamia tuhoja rukiin oraissa.

Myös Sclerotinia borealiseen nähden on eri ruislajikkeiden kestävyys vaihteleva. Esimerkkinä tästä ovat taulukossa 7 esitetyt kaksi Ruotsin kylvösiemenyhdistyksen Jämtlandin haaraosastossa suoritettua koetta. Kestävimmät sientä vastaan olivat näissä kokeissa lajikkeet Björn, Norrbotten, ångermanladilaiset jalosteet sekä Sangaste. Alttiimpia lajikkeita taas olivat Jalostettu Vaasa II, kaikki Svalöfista peräisin olevat jalosteet sekä n:o 16 Jämtlandista. Syysvehnäkokeet olivat samassa paikassa samaan aikaan kokonaan turmeltuneet $S$. borealisen vuoksi, ja sieni aiheutti samana talvena koko Norrlandissa suuria vahinkoja.

Syysvehnälajikkeet ovat huomattavasti herkempiä S. borealisen tuhoille kuin ruis, ja jos rukiissa esiintyy voimakas saastunta, vehnä tuhoutuu tavallisesti kokonaan. Taudin esiintyessä lievempänä on eri lajikkeiden välillä todettavissa taudinkestävyyden eroavuutta, vaikkakaan ei suurta. Parista kokeesta kävi selville, että suomalainen Varma-lajike näytti olevan kestävämpi sientä vastaan kuin samassa kokeessa olleet ruotsalaiset lajikkeet.

Eri nurmiheinälajien alttius Sclerotinia borealisen suhteen on vaihteleva. Sieni saastuttaa voimakkaasti mm. koiranruohon, englantilaisen raiheinän ja niittynurmikan. Useimpien rehuheinien eri kantojen kestävyydessä on eroavuuksia. 


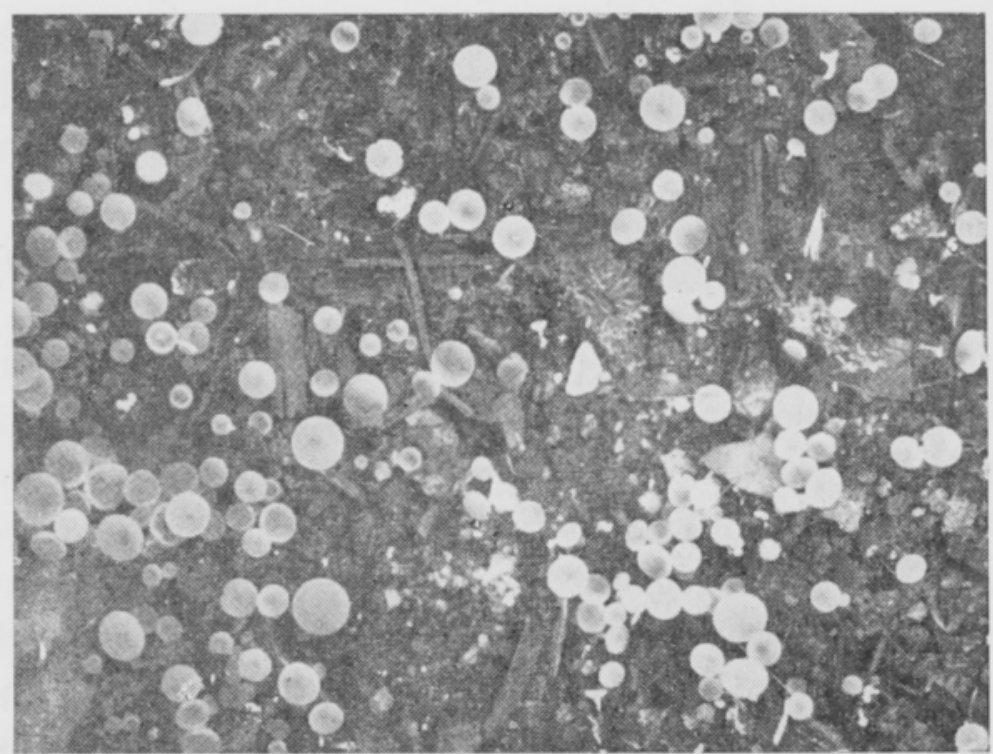

Foto H. Ekstrand.

Kuva 5. Sclerotinia borealisen kctelomaljoja.

Fig 5. Sclerotinia borealis, fruktkroppar.

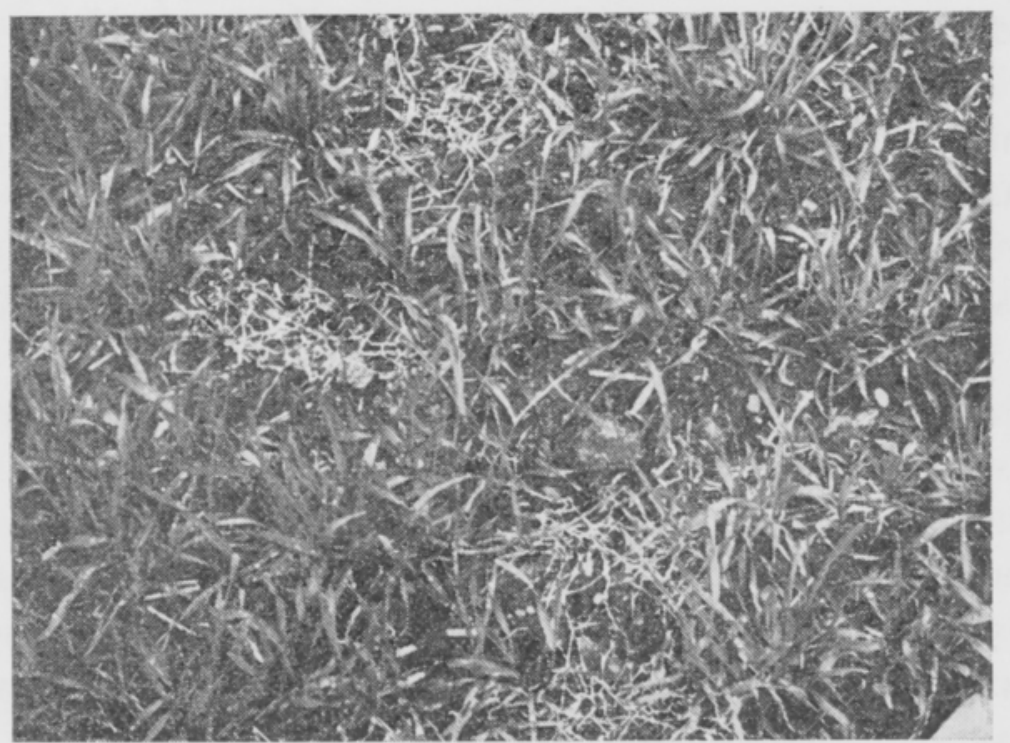

Foto H. Ekstrand.

Kuva 6. Sclerotinia borealisen tuhoja rukiin oraissa Ruotsin kylvösiemenyhdistyksen haaraosastossa Torstassa, Jämtlandissa keväällä 1946.

Fig. 6. Skador av Sclerotinia borealis $i$ råg vid Sveriges utsädesförenings filial vid Torsta $i$ Jämtland våren 1946. 
Siitä voi esimerkkinä esittää kaksi koetta aronadalla, jotka oli järjestetty Ruotsin kylvösiemenyhdistyksen Norrbottenin haaraosastossa 1941—42 (taul. 8). Täällä olivat pohjoiset lajikkeet ja alkuperät eteläisiä lajeja kestävämmät.

\section{Lajikevalinta ja kasvinjalostus talvehtimissieniä silmälläpitäen.}

Edelläesitetyt tutkimukset osoittavat, että eri syysviljalajikkeiden ja erilaisten nurmiheinäkantojen välillä on suuria eroavuuksia kestävyydessä talvehtimissieniä vastaan. Tästä syystä seuduilla, joissa näitä sieniä tavataan, on lajikevalinnalla koetettava saada mahdollisimman kestäviä lajikkeita ja kantoja.

Suurin piirtein katsoen voidaan rukiista ja nurmiheinistä erottaa kaksi ryhmää lajikkeita ja kantoja, pohjoiset ja eteläiset, joista kaikki edelliset ovat kestäviä talvehtimissieniä vastaan ja jälkimmäiset alttiita. Näissä pääryhmissä ei lajikeryhmitys kuitenkaan jää samankaltaiseksi, kun kysymys on kestävyydestä eri sienitauteja vastaan. Jokin lajike voi esim. olla hyvin kestävä lumihometta vastaan, mutta verraten arka Typhulan ja Sclerotinian suhteen. Koetoiminnassa on tärkeätä, silloin kun arvostellaan kokeita, tietää, mitkä tekijät ovat eri lajikkeissa esiintyneet vahingonaiheuttajina, jotta voitaisiin tässä suhteessa määrittää lajikkeiden viljelysarvo.

Kasvinjalostuksella on kasvien taudinkestävyydelle tietysti kaikkein suurin merkitys silloin, kun kysymyksessä on talvehtimissienet. Päätehtävänä on tällöin saada maan eri paikkakunnille sellaisia lajikkeita, jotka ovat kestäviä asianomaisella alueella esiintyviä sienitauteja vastaan. Jos lajike on kovin altis talvehtimissienille, jää kysymys mahdollisimman suurien satojen saavuttamisesta toisarvoiseksi. Ennen kaikkea on tärkeätä, että perusaineisto on jalostuksessa sellaista, että sillä on edellytyksiä antaa kestäviä jälkeläisiä; toisin sanoen jalosteen vanhemmista täytyy jommankumman olla kestävä sitä tautia vastaan, jonka torjunnasta on kysymys. Valinnan on tapahduttava luonnollista tietä. Kasvien on saastuttava sillä paikkakunnalla, joita varten lajike on tarkoitus jalostaa.

Jos jokin ruislajike tai heinäkanta viljellään viljelysalueensa ulkopuolella, voi sen kestävyys vähentyä tai kokonaan hävitä tiettyjä talvehtimissieniä vastaan. Kylvösiemenen paikallisella alkuperällä on hyvin suuri merkitys, joka käy selville mm. nurminadalla Ruotsin kylvösiemenyhdistyksen haaraosastossa Norrbottenissa suoritetuista kokeista (taul 9.). Ne osoittavat, että kannoista, jotka olivat peräisin Skånesta, tuhoutui runsaammin yksilöitä S. borealisen vuoksi kuin niistä, jotka olivat Norrbottenista. Niittyheinät ja ruis suhtautuvat samalla tavalla myös Typhula borealiseen. Syysviljojen (rukiin) ja niittyheinien siemenviljelyn on tästä syystä mieluimmin tapahduttava lajikkeiden viljelysalueilla, jotta kestävyys tauteja vastaan saataisiin säilymään. Mainittakoon edelleen, että sienille alttiissa lajikkeissa tai kasvustoissa, jotka joutuvat valinnan alaiseksi, valinta voi toisinaan vaikuttaa melko pian siten, että lajikkeen kestävyys lisääntyy. Jalostuksen tai ainakin jalostusaineiston valinnan täytyy tästä syystä tapahtua tietyllä alueella, jossa jyrkkä valinta voi tapahtua. Jollei olla selvillä kylvösiemenen viljelyspaikasta tai millä viljelysalueella se on kasvanut, ei ole mahdollista lajike- tai kantakokeissa 
Taulukko 9. Siemenèn kasvupaikan vaikutus Sclerotinia borealisen aiheuttamaan tuhoon nurminatakokeissa (1. vuoden nurmi) Ruotsin kylvösiemenyhdistyksen haaraosastossa Porsögårdenissa.

Tab. 9. Proveniensens betydelse för utgangen genom angrepp av Sclerotin $i$ a bor e alis $i$ försök med ängssvingel (1sta års) vid Sveriges Utsädesförenings filial vid Porsögården.

\begin{tabular}{|c|c|c|c|}
\hline $\begin{array}{c}\text { Vuosi } \\
\text { År }\end{array}$ & $\begin{array}{l}\text { Kanta } \\
\text { Stam }\end{array}$ & $\begin{array}{l}\text { Alkuperä } \\
\text { Härkomst }\end{array}$ & $\begin{array}{c}\text { Häviämis- } \\
\% \\
\text { Utgång \% }\end{array}$ \\
\hline $1941-42$ & Bottnia $\quad$. & Skåne (Svalöv) & 63 \\
\hline , & i) & Norrbotten & 23 \\
\hline $1945-46$ & Bottnia II & Skåne (Svalöv) & 25 \\
\hline ) & ") & Norrbotten & 13 \\
\hline ; & Bottnia I . . & ) & 11 \\
\hline
\end{tabular}

määrittää tarkkaan lajikkeen viljelysarvoa ja talvehtimiskykyä. Saman lajikkeen siementä on silloin voitu viljellä eri viljelysalueilla, jolloin siihen ovat saattaneet vaikuttaa erilaiset tekijät. Voi sattua, että viljaerä, jonka siemen on viljelty lajikkeen varsinaisen viljelysalueen ulkopuolella, on taudinkestävyydessään toisenlainen kuin on luonteenomaista k.o. lajikkeelle. Tällä tavoin lajike tulee väärin arvostelluksi.

\section{Siemenen peittauksen ja kylvöajan msrkitys.}

Saastuminen lumihomeeseen voi eri paikoissa maata samana vuonna suuresti vaihdella, millä kokeiden kannalta on suuri merkitys. Edellä jo osoitettiin, että lumihomesaastunta ja kasvien kuoleminen talven aikana ovat tietyssä vuorosuhteessa siemenen saastuntaan. Monissa tapauksissa vaikuttaa maasaastunta lumihomeen esiintymiseen, ja tällöin on saastunnan ja viljan taudinkestävyyden välillä suoranainen korrelaatio. Monesti on myös peitatussa viljassa oraiden tuhoutuminen runsasta, jos olosuhteet talven kuluessa ovat suotuisat Fusarium-sienien esiintymiselle. Oraiden kuoleminen on silloin tietenkin suurin fusariumeille alttiimmissa lajikkeissa. Toisinaan voi kuitenkin tapahtua, että kestävien lajikkeiden siemen

Taulukko 10. Typhula itoanan aiheuttama häviäminen syysvehnän lajike- ja kylvöaikakokeessa Renshammarissa, Bollnäsissa $1944-45$.

Tab. 10. Utgång pågrund av angrepp av $T$ y $p$ h u l a $i$ to a n a $i$ kombinerat sort-och såtidsförsök med höstvete vid Renshammar, Bollnäs 1944-45.

\begin{tabular}{|c|c|c|c|}
\hline \multirow{2}{*}{$\begin{array}{c}\text { Vehnälajike } \\
\text { Vetesort }\end{array}$} & \multicolumn{3}{|c|}{$\begin{array}{l}\text { Häviämis-\% } \\
\% \text { utgång efter }\end{array}$} \\
\hline & $\begin{array}{c}\text { Kylvö } \\
21 / 8 \\
\text { sådd }\end{array}$ & $\begin{array}{c}\text { Kylvö } \\
5 / 9 \\
\text { sådd }\end{array}$ & $\begin{array}{c}\text { Kylvö } \\
19 / 9 \\
\text { sådd }\end{array}$ \\
\hline Ergo ..... & 65 & 36 & 27 \\
\hline $\begin{array}{l}\text { Gluten .... } \\
\text { Maatiainen }\end{array}$ & 44 & 30 & 21 \\
\hline Lantvete .. & 25 & 16 & 15 \\
\hline
\end{tabular}


on voimakkaasti saastunut ja sen vuoksi niiden tuhoutuminen talven kuluessa voi olla yhtä suuri tai suurempikin kuin alttiissa lajikkeissa, jos viimeksimainitut ovat olleet peittauksen ansiosta vapaat sienistä tai vain lievästi niiden saastuttamia. Kun siis arvostellaan oraiden häviämisen syitä talven aikana, täytyy tietää ei vain peitatun, vaan myös peittaamattoman siemenen homeisuus. Muussa tapauksessa lajike tai heinäkanta saattaa tulla kokeissa väärin arvostelluksi.

Vertailevissa lajikekokeissa käytettiin aina peitattua siementä. Toivottavaa on, että myös käytännössä kaikki viljan siemen säännöllisesti peitattaisiin vuosittain. Kaikki kokeeni ovat osoittaneet peittauksen merkityksen, siten että peittauksen jälkeen on saatu kauttaaltaan parempi kasvusto oraille syksyllä kuin peittaamatta. Edelleen on todettava, että saastunta lumihomeeseen myös silloin, kun lumihomevahinkoja esiintyy peittauksen jälkeen, on säännöllisesti paljoa vähäisempi peitatuissa kuin peittaamattomissa kasvustoissa. Myös muut vahingot, kuten jäätymisen ja veden aiheuttamat, ovat vähäisemmät peitatussa kuin peittaamattomassa viljassa, johtuen siitä, että peitattujen siemenien oraiden juuret ja muukin kehitys on syksyllä parempi kuin peittaamattomien.

Parhaan kylvöajan määrittämiseksi on tehty paljon kylvöaikakokeita. Näiden merkitystä en aio lähemmin käsitellä. Mainittakoon ainoastaan, että niistä voidaan usein tehdä johtopäätöksiä talvehtimissienien saastutusajasta ja muistakin sienien saastuntaa koskevista seikoista. Esimerkki tästä nähdään taulukossa 10 , jossa on esitetty syysvehnällä Helsinglandissa talvella 1944--45 tehty koe. Se osoittaa, että Typhula itoana-saastunta oli voimakkain aikaisemmissa kylvöissä, samalla kun luvuista voidaan päätellä, että eri vehnälajikkeiden kestävyydessä on eroavuuksia.

\section{Kasvinravintoaineiden merkitys.}

On varmaa, että ravintoaineolosuhteet maassa vaikuttavat talvehtimissienien saastuttamiskykyyn tai oikeammin sanoen kasvien ravintoainepitoisuudella on merkitystä niiden kestävyydessä talvehtimissieniä vastaan. Se voidaan päätellä lannoitus- ja kalkituskokeista. Oraiden vastustuskyvyn lisääntymisessä näyttää fosforihapolla olevan tärkein merkitys. Mainittakoon siitä pari esimerkkiä. Suomen Suoviljelysyhdistyksen koeasemalla Tohmajärvellä oli kesällä v. 1946 ruiskoe nousevilla typpimäärillä yhdistettynä fosfaatti- ja kalilannoitukseen. Siellä todettiin, että lannoittamattomissa ruuduissa oraiden tuhoutuminen oli hyvin suuri pääasiallisesti lumihomeen ja Sclerotinia borealisen vuoksi, samalla kun sellaisilla ruuduilla, jotka olivat saaneet peruslannoituksena fosfaattia ja kalia, oraiden häviäminen oli vähäistä. Typpilannoituksella ei ollut mitään vaikutusta sienisaastunnan suuruuteen. Myös eräissä nurmikokeissa olivat olosuhteet samankaltaiset, nimenomaan timotein kestävyydessä Sclerotinia borealista ja Typhula borealista vastaan. Monivuotiset kokeet osoittavat edelleen, että vanhemmissa niityissä timotein kasvusto oli lannoittamattomissa ruuduissa huomattavasti heikompi kuin fosfaatteja ja kalia saaneissa ruuduissa. Kauniin esimerkin tarjoaa tässä suhteessa kuva 7 , jossa monivuotisen maanparannus- ja lannoituskokeen neljännen vuoden nurmessa 


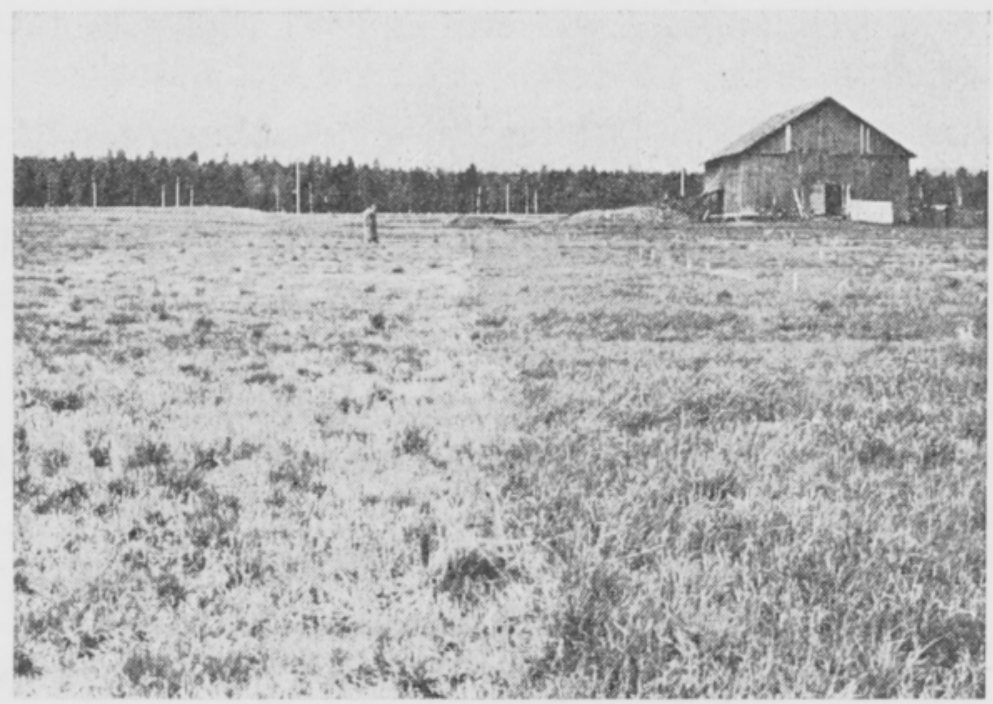

Foto H. Ekstrand.

Kuva 7. Maanparannus- ja lannoituskoe Suomen Suoviljelysyhdistyksen koeasemalla Tohmajärvellä. Ero kasvustossa lannoittamattoman (vasemmalla) ja lannoitetun (oikealla) ruudun välillä 4. vuoden nurmessa 7. 6. 1946.

Fig. 7. Jordförbättrings- och gödslingsförsök vid finska mosskulturföreningens station vid Tohmajärvi. Skillnaden $i$ beståndet i.4de årets vall den 7/6 1946 mellan ogödslade (till vänster) och fosfatgödslade (till höger) parceller.

timotei oli hyvin heikosti kehittynyttä lannoittamattomissa koejäsenissä, kun taas fosfaatteja saaneissa ruuduissa kasvu oli hyvä. Tässä tapauksessa ovat talvehtimissienet aikaisempina vuosina varmasti jossakin vaiheessa olleet syynä eroavuuksiin. Suomessa on mm. maisteri A. TAINIO (17) osoittanut, että fosfaattilannoitus lisää huomattavasti rukiin talvenkestävyyttä. Talvenkestävyys on tässä tapauksessa epäilemättä sama kuin kestävyys talvehtimissieniä vastaan.

\section{Yhteenveto.}

Edelläesitetyt näkökohdat voidaan yhdistää seuraavasti.

Käytännön maataloutta varten on tärkeätä:

1) valita lajikkeet ja kannat niistä syysviljoista ja nurmiheinistä, jotka ovat talvehtimissieniin nähden vastustuskykyisiä;

2) ottaa huomioon kylvösiernenen laatu, ennen kaikkea syysviljoilla, ja mahdollisuuksien mukaan välttää käyttämästä kylvösiementä, joka peittaamattomana on runsaasti Fusarium-sienien saastuttama;

3) että kylvösiemenen peittaus on ehdottoman välttämätöntä;

4) että kylvösiemeneksi käytetään mikäli mahdollista viljelysalueella tuotettua siemenviljaa;

5) että maan ravintoainevaroista, ennen kaikkea fosfaatin tarpeesta huolehditaan sopivilla lannoitteilla.

Jalostustoiminnassa ovat tärkeimmät näkökohdat:

1) että jalostus tapahtuu oikealla tavalla talvenkestävyyden selvittämiseksi, 
ottaen huonioon sekä kylmänkestävyys että ennen kaikkea kestävyys eri talvel timissieniä vastaan;

2) että jalostus tai ainakin jalostusaineiston valinta tapahtuu itse viljelysalueilla.

Koetoimintaa varten yleensä haluan viitata sen seikan tärkeyteen, että talvehtivien kasvien kokeita arvosteltaessa ei ole otettava huomioon vain pelkkiä satolukuja sellaisenaan, vaan myös:

1) eri lajikkeiden ja kantojen vastustuskykysuhteet;

2) kylvösiemenen laatu ja kylvösiemenen saastunta sekä peitattuna että ennen kaikkea peittaamıattomana;

3) talvehtimisvahinkojen laatu ja laajuus sekä sato- ja lajikekokeissa että myös muissa kokeissa, erityisesti lannoituskokeissa;

4) edelleen, ettei turhanpäiten hylätä kokeita, jotka näyttävät huonoilta ja joissa monia ruutuja on talven aikana tuhoutunut.

Tästä kaikesta johtuu, että siemenviljelyksiä olisi lisättävä useilla alueilla, ennen kaikkea pohjoisessa, missä tähän saakka enempää Ruotsissa kuin Suonıssakaan ei ole voitu tuottaa riittävästi eri lajikkeiden eikä kantojen siementä.

\section{Loppupäätelmä.}

Osa tässä esitetyistä nảkökohdista on verraten uusia, mutta uskon, että jos kasvipatologiset kysymykset otetaan riittävästi huomioon ja kokeet järjestetään vastaisuudessa varsinaisen kasvinviljelyn ja kasvipatologiaa edustavien koetoimintamiesten yhteistyönä, saavutetaan nopeamnin tuloksia. Kasvipatologiset näkökohdat tulevat aiheuttamaan sen, että monet kysymykset voidaan ratkaista paljoa yksinkertaisemmalla ja tehokkaammalla tavalla. Tämä ei koske vain edelläkäsiteltyjä kysymyksiä, vaan monia muitakin kasveja koskevia probleemeja. Ennen muuta tässä on kysymyksessä syrjäseudut, kasvinviljelyn kannalta "köyhimmät» osat sekä Ruotsissa että muussa Skandinaviassa, varsinkin pohjoiset osat, jotka kysynıksen ollessa ilmastosta, maatalousolosuhteista, kasvilajikkeista jne. ovat paljon jäljessä vanhoista maatalousalueista, joissa vuosisatojen intensiivinen viljelys on lisännyt mahdollisuuksia. Suurilla maatalousalueilla Skandinavian eteläosissa on luonnollinen valinta ja viime vuosıkymmeninä myös jalostus- ja koetoiminta auttaneet varmistamaan satotuloksia. Tieteen uusimmat tulokset auttavat kuitenkin valtaamaan uusia alueita ja maatalous voidaan saada niissä entistä kannattavammaksi. Kasvipatologia voi siinä antaa panoksensa, jota ei ole aliarvisitava. Se voi olla tehokkaalla tavalla apuna, siten että voitetaan huomattavasti aikaa. Varsinkin kun otetaan huomioon kasvien taudinkestävyyden tutkimukset ja niiden tuloksia käytetään tehokkaasti hyväksi, voidaan ehkä muutamissa vuosissa saavuttaa se, mitä »luonnollinen» kehitys on aikaansaanut vuosisatojen aikana etelässä. Järjestämällä erikoiskokeita edelläkäsiteltyjen kysymyksien selvittäniseksi voidaan melkoisella varmuudella jo verraten harvoilla kokeilla, edellyttäen että talvehtimisolosuhteet ja kasvitautien esiintyminen ovat sopivat, saada tulokset ja vastaukset kysymyksiin, jotka muuten vaativát vuosikymmeniä tullak- 
seen ratkaistuiksi. Nykyisin vallitsevissa olosuhteissa, ennen muuta Suomessa, katson olevan syytä ottaa epäröimättä huomioon nämä uudemmat näkökohdat. Tässä ei ole kysymyksessä niinkään paljon lisätä tuotantoa suurilla maatalousalueilla, vaan lisätä ja varmentaa sekä tehdä luotettavammaksi maatalous syrjäisemmillä seuduilla ja »laihemmissa» osissa maata sekä tehdä kohtuullisessa ajassa maatalous ennen muuta pohjoisessa entistä kannattavammaksi.

\section{KIRJALLISUUTTA.}

(1) ANdersson, G. 1934 - Undersökningar rörande rågens vinterhärdighet. Svenska Utsädesförenings Tidskr., 44, p. 409.

(2) Ekstrand, H., 1937 - Trådklubba på vintersäd. Växtskyddsnotiser, 1, p. 3.

(3) —- 1937 - Sklerotiesjuka på fodergräs. Ibid., 1, p. 4.

(4) — — 1938 - Vinterskador på höstsäden. Ibid., 2, p. 5.

(5) ——— 1938 - Några ekonomiskt viktiga sjukdomar på höstsäd och vallväxter. Statens Växtskyddsanstalts Meddelande, 25.

(6) —-- 1939 - Höstsädens och vallväxternas övervintring. Växtskyddsnotiser, 3, p. 16.

(7) —— 1940 — Skadorna på höstsäden under vintern 1939—40. Ibid., 4, p. 33.

(8) —i)— 1942 - Årets vinterskador på höstsäd och vallar. Ibid., 6, p. 38.

(9) —— 1943 - Höstsädens och vallarnas övervintring 1942-43. Ibid., 7, nr. 3, p. 13.

(10) —- $1944-$ Höstsädens och vallarnas övervintring 1943-44. Ibid., 8, p. 50.

(11) —— 1945 - Höstsädens och vallarnas övervintring vintern 1944 45. Ibid., 9, p. 49.

(12) —- 1946 - Höstsäden och vinterhärdighetsproblemet. Ibid., 10, p. 15.

(13) —- 1946 - Höstsädens och vallarnas övervintring 1946. Ibid., 10, p. 44.

(14) —- - 1946 - Förekomsten av utvintringssvampar på höstsäd och vallväxter i Finland. $\angle$ Ibid., 10 , p. 49.

(15) —— 1946 — Några växtpatologiska synpunkter på höstsäd- och vallodlingen i Norrland. Ibid., 10 , p. 68 .

(16) ——— 1947 - Höstsäden och vinterhärdighetsproblemet, med speciell hänsyn till resistensförhållandena. Statens Växtskyddsanstalts Meddelande. Käsikirjoitus (manuskript).

(17) TAINIO, A. 1946 - Fosfatgödslingens betydelse för höstsådden. - Praktisk Försöksverksamhet, 3 , nr. 8 , p. 1 .

(18) Ånerman, Å. 1927 - Studien über den Kältetod und die Kälteresistenz der Pflanzen. Lund 1927.

(19) - - - , Andersson, G. \& LindberG, J. E. 1935 - Studien ǔber die Winterfestigkeit des Roggens. Zeitschr. f. Züchtung, Reihe A., 20, p. 137.

\section{REFERAT. \\ NÅGRA VÄXTPATOLOGISKA SYNPUNKTER PÅ ÖVERVINTRINGEN AV HÖSTSÄD OCH VALLGRÄS.}

Ref. av föredrag vid försöksdagarna i Helsingfors 25. 2. 1947.

H. EKSTRAND.

Statens Växtskyddsanstalt, Stockholm, Sverige.

Samarbetet mellan försöksverksamhet på jordbrukets område och den växtpatologiska verksamheten måste utökas, varigenom en hel del av resultaten snabbare skulle komma lantbruket och växtodlingen tillgodo. Hittills har huvudsakligen vid sammanställningar av försök hänsyn tagits till av- 
kastningssiffrorna och mycket litet gjorts för att utreda vilka faktorer, som åstadkomma de stora variationerna i avkastningen. I det följande belyses nödvändigheten av att försöksverksamheten måste få ett intimare samarbete med den växtpatologiska verksamheten, för att en del av dessa faktorer skola utredas och därigenom snabbare och bättre resultat skola erhållas av en del växtodlingsförsök. Här framläggas en del av de resultat som erhållits under studier över höstsädens och vallgräsens övervintring, vilka kunna belysa detta.

Vad som till största delen ligger till grund för undersökningarna över resistens ej blott mot kyla utan även mot de parasitära vintersjukdomarna är en serie rågförsök, som varit utlagda i olika delar av Sverige, och vidare höstsädes- och vallväxtförsök, som utlagts av hushållningssällskapen, statens försöksgårdar och Sveriges utsädesförenings filialer.

Hos vete finnes efter undersökningar av Åkerman m.fl. (1, 18 och 19) olika resistens mot kyla hos olika sorter. Hos råg skulle enligt en del laboratorieförsök även olika sorter ha olika köldresistens, men enligt författarens undersökningar har hittills ej något sådant kunnat iakttagas på fältet. I ett par rågförsök i Skåne 1939—40, en av de extremt kalla vintrarna, då vetet skadades mycket svårt av kyla, visade sig emellertid, att „köldskadorna” stodo i korrelation till utsädets beskaffenhet, så att några verkliga köldskador ej förelågo, utan att endast de genom Fusarium-angrepp försvagade plantorna hade varit mindre köldhärdiga (tab. 1). Ju större Fusarium-smittan var på utsädet, desto större var utgången av kyla under vintern, oberoende av om sorterna tillhörde de enligt ÅERMAN och ANDERSSON m.fl. mot kyla resistenta och de enligt författarens undersökningar mot Fusarium resistenta sorterna eller de mot dessa mera mottagliga sorterna. Efter betat utsäde var utgăngen mindre än efter obetat, men även där stod utgången i korrelation till smittograden av det obetade utsädet. Inga verkliga köldskador ha iakttagits på råg under alla de år dessa undersökningar varit i gång. Variationer i övervintringen kan således uppkomma genom att utsädet varit olika starkt Fusarium-smittat och därigenom olika känsligt för köldskador.

Många av de utlagda rågförsöken ha visat, att olika sorter äro mycket olika resistenta mot angrepp och utgång genom snömögel, förorsakat av Fusavium nvale (tab. 2 och 3). Detta framträder däri, att de mera resistenta sorterna vid starkt snömögelangrepp ej visa så stor utgång som de mera mottagliga, även om utsädet varit starkt Fusarium-smittat. Vid starka snömögelangrepp kunna de mottagliga sorterna helt gå ut, under det att de resistenta vanligen ha ett relativt gott bestånd. Även efter betning av utsädet kan utgången vara mycket stor hos de icke resistenta sorterna. I stort sett kan rågsorterna fördelas på tvă grupfer, en resistent, till vilken höra bl.a. de finska sorterna Oiva, Toivo, vidare Sangaste, Björnråg, en del landsorter framför allt Norrbottensrågar samt midsommarrågar och en mottaglig grupp, till vilken hänföras bl.a. Förädlad Vasa II, Stål-, Kungs-, Malm- och Petkusråg.

Även hos en del vallgräs har påvisats olika resistens mot snömögel hos olika stammar bl.a. hos ängssvingel (tab. 4).

Beträffande övriga utvintringssvampar har olikheter påvisats i resistensen mot Typhula borealis och Sclerotinia borealis både hos höstsäd och vallgräs. Hos råg omfatta huvudgrupperna de samma sorterna som de två resistensgrupperna beträffande snömögel, ehuru sortfördelningen inom dessa blir olika i fråga om angreppsgraden av de olika svamparna (tab. 5 och 7 ). Vete angripes mycket starkare av dessa svampar än rågen, men även där finnes olika resistens hos olika sorter.

Hos vallgräsen är resistensen mycket olika hos olika stammar, de sydliga angripas mycket starkare både av $T$. borealis och $S$. borealis än de som ha nordlig härstamning (tab. 6 och 8).

Vad som mycket starkt måste betonas är proveniensens betydelse (tab. 9). Förädling och utsädesodling måste ske inom de odlingsområden för vilka sorterna och stammarna äro avsedda, då annars resistensen mot de olika sjukdomarna kan minskas.

Vidare måste hänsyn tagas till graden av utsädessmitta av Fusarium, då utgången genom snömögelskador under vintern står i korrelation till utsädessmittan även hos de mera resistenta sorterna. Vid starka skador visar sig även att utgången även efter betning av utsädet står i korrelation till smittan hos det obetade utsädet. För att kunna bedöma övervintringen måste man därför på analysattesten från frökontrollanstalt alltid ha graden av utsädessmittan angiven för det obetade utsädet. Även betningens stora betydelse måste påpekas. 
I fråga om såtidsförsök (tab. 10) kunna av dem erhållas data beträffande tiden för infektionen av de olika svamparna i olika delar av landet, vilket har stor betydelse för bestämningen av den bästa såningstiden.

Av en del gödslingsförsök framgår mycket tydligt, att näringsförhållandena i hög grad påverka angreppen av utvintringssvamparna, i det att om någon brist föreligger, bli svampangreppen starkare. Några speciella försök äro ännu ej gjorda för att utröna dessa förhållanden, men allting tyder på att fosforsyran har den största betydelsen. De iakttagelser, som gjorts på ett flertal försök, kunna ej tydas på annat sätt, bl.a. visar en del finska (fig. 7) och svenska försök att fosfatgöđslingen höjer rågens vinterhärdighet.

De framlagda synpunkterna kunna sammanfattas på följande sätt.

För det praktiska lantbruket är det av betydelse:

att välja sorter och stammar av de övervintrande grödorna, vilka äro motståndskraftiga mot utvintringssvamparna;

att taga hänsyn till utsädets beskaffenhet framför allt hos höstsäden, och att i möjligaste mån undvika att begagna utsäde, som i obetat tillstånd är starkt Fusarium-smittat;

att betning av utsädet är absolut nödvändig;

att utsäde i möjligaste mån begagnas från utsädesodlingar inom odlingsområdet;

att näringstillståndet i jorden framför allt att fosfatbehovet tillgodoses genom lämpliga gödselgivor.

För förädlingsverksamheten äro de viktigaste synpunkterna:

att förädlingen sker på rätt sätt för att få fram vinterhärdigheten, ej blott genom att hänsyn tages till köldhärdigheten utan framför allt till resistensen mot de olika utvintringssvamparna;

att förädlingen eller åtminstone selektionen sker inom de avsedda odlingsområdena.

För försöksverksamheten i övrigt måste påpekas vikten av att vid bedömningen av försök med de övervintrande grödorna taga hänsyn ej blott till de rena avkastningssiffrorna som sådana utan även: till resistensförhållandena hos de olika sorterna och stammarna;

till utsädets beskaffenhet och utsädessmittan ej blott i betat utan framför allt i obetat tillstånd; till vinterskadornas art och omfattning ej blott i avkastnings- och sortförsök utan även i andra försök, särskilt gödslingsförsök;

vidare att ej i onödan slopa försök, som se fula ut och ha haft stor utgång under vintern, då sådana försök ofta kunna visa mycket goda utslag beträffande här herörda förhållanden.

Till allt detta kommer att utsädesodlingarna måste ökas inom flera områden framför allt norrut, där hittills varken i Sverige eller Finland tillräckligt med utsäde av olika sorter och stammar kunnat produceras.

En del av de framlagda synpunkterna äro nya och som avslutning påpekas ytterligare vikten av att tillräcklig hänsyn måste tagas till de växtpatologiska frågorna. I många fall kunna dessa synpunkter bidraga till en snabbare och effektivare lösning av många växtodlingsproblem. Samarbetet mellan växtpatologerna och försöksmännen inom jordbruksforskningen för övrigt måste ökas, och framför allt resistensfrågorna måste bli föremål för en intensivare bearbetning. Under de rådande förhållandena i Skandinavien framför allt i Finland behöver man med det underlag som nu finnes ej vara rädd för att taga upp en del nyare synpunkter. Här gäller ej så mycket att öka produktionen inom de stora jordbruksområdena, utan att öka den och göra den säkrare och pålitligare framför allt inom de mindre och "magrare" delarna av landet och på rimlig tid göra de mindre jordbruken framför allt norrut mera bärande. 